\title{
Do Ethical Purchase Intentions Really Lead to Ethical Purchase Behavior? A Case of Animal-Testing Issues in Shampoo
}

\author{
Alexandra Madar ${ }^{1}$, Hazel H. Huang ${ }^{1} \&$ Ting-Hsiang Tseng ${ }^{2}$ \\ ${ }^{1}$ Durham University Business School, Durham, UK \\ ${ }^{2}$ College of Business, Feng Chia University, Taichung, Taiwan \\ Correspondence: Ting-Hsiang Tseng, College of Business, Feng Chia University, No. 100 Wenhwa Rd., Seatwen, \\ Taichung 40724, Taiwan. Tel: 886-9-2173-1529. E-mail: tsength@fcu.edu.tw
}

\author{
Received: May 21, $2013 \quad$ Accepted: June 13, $2013 \quad$ Online Published: June 20, 2013 \\ doi:10.5539/ibr.v6n7p102 URL: http://dx.doi.org/10.5539/ibr.v6n7p102
}

\begin{abstract}
This study investigates the impact of consumers' ethical buying intentions on their buying behavior. Using a survey approach, the findings suggest the link between ethical buying intentions and behavior depends on consumers' awareness of the brand's general corporate social responsibility activities. Only when consumers with ethical purchase intentions are aware of the brand's CSR activities can their intentions translate into behavior.
\end{abstract}

Keywords: CSR, CSR awareness, ethical buying behavior

\section{Introduction}

Corporate social responsibility (CSR) has gained increasing attention from individual consumers, policy makers, and companies. CSR represents the deliberate engagement of the company to allocate resources to social or ethical actions beyond the financial and shareholders' obligations (Brown \& Dacin, 1997), and has become part of the corporate image which influences consumers' product choice (Brown \& Dacin, 1997). Because of its potential in influencing consumers' purchase decision, companies are encouraged to spend significant resources on socially responsible causes in the hope to achieve an increase in their profits (Drumwright, 1996). Although many studies speculates a positive relationship between financial performance and firms' CSR involvement (Brown \& Dacin, 1997; Ehrich \& Irwin, 2005; Luo \& Bhattacharya, 2006; Sen \& Bhattacharya, 2001), the effects of CSR on financial performance have been disappointing as the relationship they found was either weak (Pava \& Krautz, 1996, Waddock \& Graves 1997) or non-existent (Freedman \& Jaggi, 1982). To understand the reason why the relationship between CSR and financial performance is weak, it is necessary to unravel the relationship between ethical buying intentions and actual ethical buying behavior from consumers' point of view. While most studies use experimental approaches to study ethical buying behavior, an approach that is able to tap into consumers' ethical intentions and actual behavior is necessary to understand this relationship. Therefore, using a real case from animal-testing evidence in shampoos, we investigate the relationship between ethical buying behavior and actual buy intention.

According to Ajzen's (1991) theory of planned behavior, a positive relationship exists between purchase intention and purchase behavior. However, Sproles et al. (1978) argue that "efficient decision making requires consumers to be fully informed regarding ethical issues." That is to say, for consumers with less or no ethical commitments, this does not transmit into ethical buying when they possess sufficient ethical information (Papaoikonomou \& Ginieis, 2011). However, committed ethical consumers actively seek ethical information and act accordingly (Ehrich \& Irwin, 2005). For those committed ethical consumers, CSR knowledge guides their ethical behavior. As a result, CSR knowledge is a prerequisite for ethical buying, but does not necessarily cause ethical buying.

Existing CSR studies have taken the position that consumers have enough knowledge of the company's CSR engagement (Brown \& Dacin, 1997; Ehrich \& Irwin, 2005; Luo \& Bhattacharya, 2006; Sen \& Bhattacharya, 2001). However, this assumption is problematic because it does not reflect most of the real situations; that is, consumers are generally not aware of company's (or a brand's) CSR engagement. It is possible that the weak relationship between CSR spending and company's financial performance is caused by the lack of CSR 
engagement information. Limited empirical study has investigated this possibility; therefore, to advance our understanding of consumers' ethical buying behavior, the current study examines consumers' CSR reaction by using a real situation and a real product; that is, animal testing issues in shampoo and consumers' actual shampoo buying behavior.

\section{Theoretical Background}

\subsection{Corporate Social Responsibility (CSR)}

CSR can be used as a purely economic tool (e.g. satisfying shareholders) or can take a more proactive social dimension (e.g. The Body Shop community trade support); therefore, it is broadly defined as an organization's obligations to act proactively to protect or improve the welfare of society as a whole (Brown \& Dacin, 1997; Sen $\&$ Battacharya, 2001). There are six domains in which social responsibility actions can take place, including community support, diversity, employee support, environment, non-home country, and product (Table 1; Sen \& Bhattacharya, 2001). These domains show the multifaceted aspects of the CSR and emphasize the obligations that businesses have to society.

Table 1. CSR domains

\begin{tabular}{ll}
\hline Domain & Example \\
\hline 1. Community support & Educational and housing initiatives for the economically disadvantaged \\
2. Diversity & Race, family and sexual orientations, disability based diversity record and initiatives within and outside the firm \\
3. Employee support & Concern for safety, union relations, profit sharing, employee involvement, job security \\
4. Environment & Environment friendly products, animal testing, hazardous-waste management, recycling, pollution control \\
5. Non-home country & Overseas labour (including sweatshops), operations in countries with human rights violations \\
6. Product & Product safety, research and development/innovation, antitrust disputes \\
\hline
\end{tabular}

CSR represents the deliberate engagement of the company to allocate resources to social or ethical actions. To act socially or ethically, a company is able to generate financial benefits as CSR can drive a positive corporate image; thereby resulting in consumers' favorable product evaluation (Brown \& Dacin, 1997). Companies' objectives for engaging in spending resources for certain CSR domains go beyond fulfilling external obligations. Companies allocate resources on social causes mainly to increase competitive advantage, improve stock market performance, and ultimately enhance profitability (Drumwright, 1996). Unfortunately the effects of CSR on financial performance have mixed outcomes. Analyzing 21 companies by looking at previous studies, Pava and Krautz (1996) found that socially responsible firms perform only slightly better than non-socially responsible firms. But other studies, such as that of Freedman and Jaggi (1982), found no such relationship. These mixed findings suggest that CSR seems to have 'at best a weak, positive relationship with financial performance' Sen and Bhattacharya (2001, p. 226). So, what makes the weak, if any, connection between CSR and the company's performance?

\subsection{The Relationship between Ethical Buying Intention and Actual Ethical Buying Behavior}

Existing studies have examined the relationship between CSR and product purchase behavior by using situations in which consumers made purchasing decisions while signifying the concept of CSR (Chandon, Morowitz, \& Reinartz, 2005; Sheppard et al., 1988; Wilson, Mathews \& Harvey, 1975). This relationship is logical since according to Ajzen's (1991) theory of planned behavior, a positive relationship exists between purchase intention and purchase behavior. To be more specific, Ajzen's (1991) theory of planned behavior suggests that intention is determined by three factors: attitudes towards the behavior (favorable or unfavorable evaluation of the behavior), subjective norms (perceived social pressure regarding the performance of the behavior) and perceived behavioral control (estimation of performing the behavior reflecting past experience and anticipated obstacles). The magnitude of the influence of each factor in the prediction of intention varies depending on the behavior and situations. Furthermore, the theory emphasizes the fact that only a person's salient beliefs influence a person's intentions and actions. These salient beliefs lead to the development of attitudes about the object in question. These positive relationships have been confirmed in the psychology (Bruvold, 1972) and marketing (Kolodinsky et al., 2010) literature: both beliefs and behavior are related to attitudes. In other words, people who show more empathy and care about others also consider CSR as being important in the business environment.

However, what current literature has found is buying intention does not necessarily lead to actual buying behavior (Freedman \& Jaggi, 1982; Pava \& Krautz, 1996; Waddock \& Graves, 1997). We agree with Ajzen (1991) that attitudes are an essential source of intention; however, we argue that this intention does not always lead to behavior. This is because the relationship between purchase intention and actual purchase behavior is 
dependent on the buying situation (Bonfield, 1974). Since a person's salient beliefs can be reflected in situations where the attitudes are developed about the object in question (Ajzen, 1991), it is only logical to propose this relationship. However, criticisms of this type of study indicate that the situation in the previous studies differs from reality (Brown \& Dacin, 1997; Sen \& Bhattacharya, 2001). Most consumers are not reminded of CSR when making a purchase decision in reality, compared with the study contexts where a specific CSR situation is delineated. Because of this, we propose that while the attitudes towards CSR directly influences ethical purchase intention (H1a), their ethical purchase intention does not lead to their actual ethical behavior (H1b).

H1a: There is a positive relationship between the attitudes towards ethical behavior and ethical purchase intention.

H1b: There is no clear relationship between ethical purchase intention and actual ethical buying behavior.

\subsection{The Moderating Role of Awareness in the Relationship between Purchase Intention and Ethical Buying Behavior}

A necessary part of the product choice, which occurs before the choice decision is product evaluation, which is an overall judgment of the product with respect to the existing alternatives. For the product evaluation to take place, consumers need to possess information about the product or about the company. Being informed about the company's CSR implies having some knowledge about the company, which in turn can influence consumers' product evaluation. If the consumer holds an overall positive evaluation about the company's CSR, this may have a positive impact on the product evaluation (Brown \& Dacin, 1997).

Information about the company's social and ethical actions can take the form of product ethical attributes available on the product packaging. Ehrich and Irwin (2005) define ethical attributes as "attributes that reflect a person's conscience" (p.267), and are related to the ethical values that a person holds. Thus, CSR and ethical attributes are two concepts which are linked. CSR refers to the information about the company regarding social and ethical issues and ethical attributes refer to the ethical information that is available at the purchasing point about these ethical issues. Attribute information about the ethical practice of the company is not always easily available. Chattopadhyay and Alba (1988) show that attitudes about a product are influenced by the product attributes recalled when the evaluation of the product takes place. Thus, if ethical attributes about a product are not available in the memory or on the packaging, these cannot influence consumers' product evaluation.

Existing studies showed that company's CSR influences customers' buying decision indirectly by influencing their perception about the company, which can have an impact on the product evaluation and thus on their product choice (Brown \& Dacin, 1997; Sen \& Bhattacharya, 2001). These studies examined the relationship between CSR and product purchase behavior, using situations in which consumers made purchasing decisions while being familiar with the CSR (Brown \& Dacin, 1997; Sen \& Bhattacharya, 2001). More specifically, they found that CSR activities affect consumers' purchase intention by establishing the proper context for the purchasing intentions to occur or for consumers who hold particular CSR beliefs. In a real world situation, when a purchasing decision is made, information about CSR, such as labour practice, environmental friendliness, animal cruelty, is not always readily available. This can in turn result in consumers' purchasing decision being contradictory to their buying intentions and beliefs. In Ehrich and Irwin's (2005) study, they found that even for most consumers who held strong ethical attitudes, they did not seek relevant CSR information prior to purchase. However when ethical attribute information is readily available, consumers consider it in their purchasing choice. These findings imply that when ethical attribute information is not available, consumers' ethical attitudes cannot influence their purchasing decision. Thus creating a situation in which CSR actions are known by the participants may not accurately reflect how CSR influences consumers' product choice in real situations. Since the awareness of CSR activities in general influence how consumers decide their purchasing choices, we argue that the ethical buying intentions can be translated into their actual buying behavior only when they are aware of the CSR activities. If there are unaware of the CSR activities, ethical buying intentions will not lead to actual buying behavior. Therefore, we hypothesize the moderating role of consumer awareness in the relationship between ethical buying intentions and their actual buying behavior.

H2: Consumers' awareness of the company's CSR activities moderates the relationship between their ethical buying intention and their actual ethical buying behavior.

Figure shows the summary of our conceptual framework. 


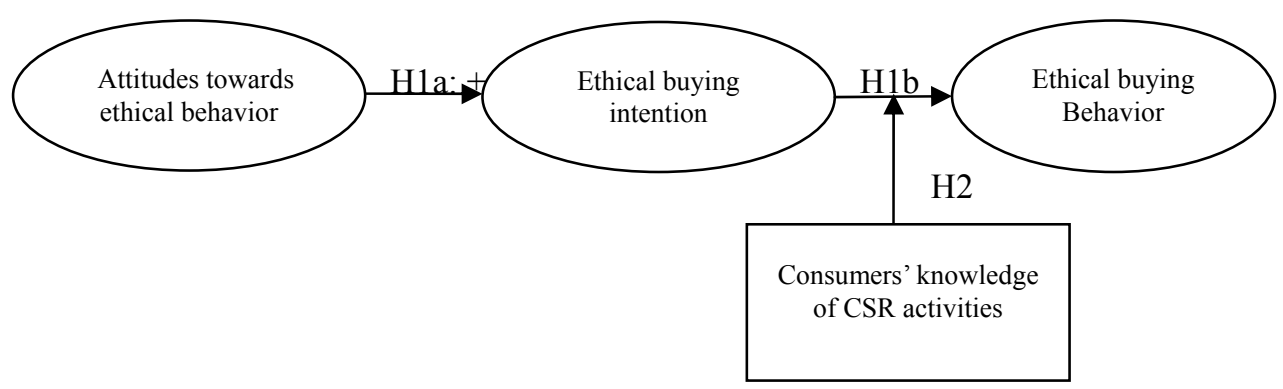

Figure 1. Conceptual framework

\section{Method}

\subsection{Context of Study}

The context of the company's animal testing policy was chosen for the current study in relation to the shampoo brand. The reasons for choosing animal testing policy are threefold. First, companies are not legally bound to engage in non-animal testing practice. As a result, those which do not test on animals are seen as engaging in an ethical activity. Secondly, consumers have different opinions about this topic. Some consumers have strong views against animal tested products while others do not seem to concern much. With a wide range of opinions regarding this issue, it is assumed that the study is able to examine if consumers' attitudes coincide with their behavior. Finally, information about animal testing is not always readily available on the shampoo packages. If consumers want to know about this information, they are required to undertake extra information search activities.

\subsection{Measures}

The questionnaire consists of four scales taken from existing literature and modified to match the animal testing context via a series of interviews and pilot studies. The scales include (1) seven items of consumers' buying intention regarding animal tested products (ethical buying intention) (Bohlen, Schlegelmilch \& Diamantopoulos, 1993), and (2) six items of attitudes towards ethical matters (ethical attitudes) (Kinnear \& Taylor, 1973; Ehrich \& Irwin, 2005). They were all measured by the nine-point Likert-type scales. The wording was modified to fit the current study context (animal testing) and refined after a discussion with 10 undergraduate students and one consumer research professional to ensure they were easy to understand. The details of the scales are displayed in Table 2 .

Table 2. Measurement scales

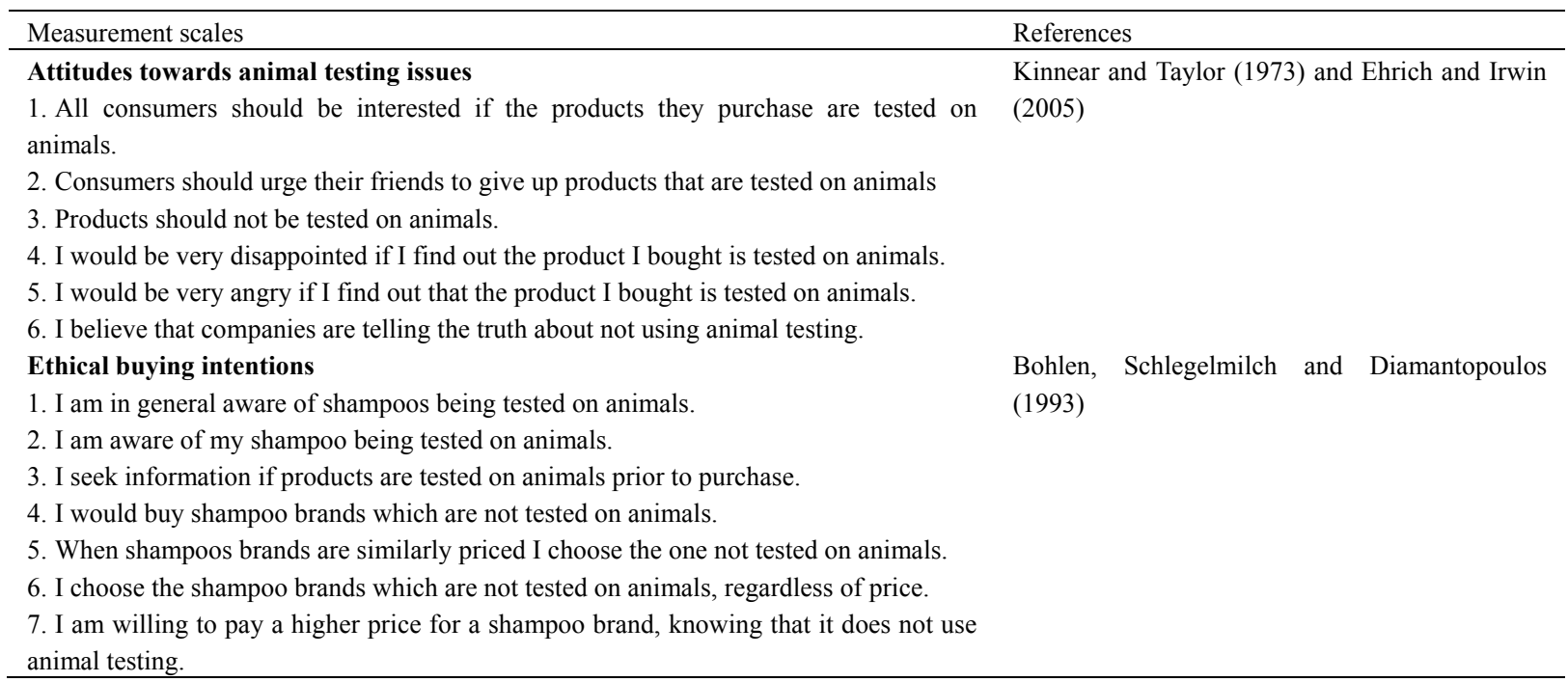

Two dichotomic (yes or no) questions regarding (1) the consumers' awareness of the CSR activities in general by the companies they buy from and (2) their awareness of the companies' animal testing policy in specific were asked. These questions were coded into dummy variables, where 0 represents 'aware of the activities' and 1 represents 'not aware of the activities'. 
One open question asked the respondents their currently used shampoo, indicating their actual ethical buying behavior. This question was coded into a dummy variable, where 0 represents an 'animal tested brand' and 1 represents a 'non-animal tested brand.' We followed Irwin \& Naylor's (2009) study to source from the Caring Consumer website (http://www.caringconsumer.com) to verify whether or not the brands use an animal testing practice.

\subsection{Sampling Procedures}

The questionnaires were distributed to students in a University in northern England. They were distributed face-to-face to undergraduate students within several accommodation halls in the University. A student sample was purposefully chosen because students have been exposed to debates about the current environment and economic situation. They are the future employees and entrepreneurs, with some of them influencing the future economic policies. Thus their opinion and behavior with respect to CSR actions is important in shaping policies regarding environmental issues.

\section{Results}

One hundred thirteen questionnaires were returned, and the sample comprised of 57\% females (57\%) and 43\% males. Of 113 respondents, $15 \%$ claimed that they knew about the company's general CSR practice, $27 \%$ claimed that they knew about the company's animal testing policy, and $28 \%$ used a shampoo brand which was not involved in animal testing practices. The results showed that the Cronbach's alphas were all above .70: consumers' ethical buying intention: .89; attitudes towards the company's CSR: .95; attitudes towards CSR in general: .87; attitudes towards ethical issues: .91; skepticism: .80. Sex did not suggest much difference in their awareness, buying intentions, actual buying behavior with regard to ethical issues, except for their attitudes towards ethical matter: females were shown more concerned about ethical matters than their male counterparts $($ Mmale=26.00, SDmale =9.41; Mfemale=32.12, SD female=9.80; $\mathrm{t}=-3.339, \mathrm{p}<.01)$.

The regression analysis showed a strong positive relationship between the respondents' attitudes towards the animal testing policies and their buying intentions of non-animal tested products $(\mathrm{R} 2=.39, \mathrm{~F}=72.27, \mathrm{p}<.01$; $\beta=.63, \mathrm{t}=8.50, \mathrm{p}<.01)$. Therefore, H1a is supported. Logistic regression analysis was carried out to examine H1b. The results showed that there was no significant relationship found between consumers' buying intention regarding animal tested shampoos and their actual buying behavior (Model 1 in Table 3). In other words, their intention of not buying animal tested shampoos did not indicate that they would buy shampoos not being tested on animals Therefore, evidence for $\mathrm{H} 1 \mathrm{~b}$ is found. Moreover, the results showed that the specific awareness of the company's animal testing policy did not demonstrate any impact to their actual ethical buying behavior. Nor did it generate interaction effect with their ethical buying intention to influence actual ethical buying behavior (Model 2, Table 3). Nevertheless, when the respondents claimed that they were aware of the general CSR activities undertaken by the companies from which they bought their shampoos and that they intended to buy non-animal tested shampoos, they tended to buy shampoos not tested on animals (Model 3, Table 3). Thus, H2 was supported.

Table 3. Logistic regression models

\begin{tabular}{|c|c|c|c|c|}
\hline \multirow[t]{2}{*}{ Independent variables } & \multicolumn{3}{|c|}{$\begin{array}{l}\text { Dependent variable: } \\
\text { Actual ethical buying behavior }\end{array}$} & \multirow{2}{*}{$\begin{array}{l}\text { Hosmer and Lemeshow Test of } \\
\text { Model Fit } \\
\chi^{2}(\mathrm{df})\end{array}$} \\
\hline & $\beta$ (S.E.) & Wald (df) & $\operatorname{Exp}(\beta)$ & \\
\hline \multicolumn{5}{|l|}{ Model 1: } \\
\hline Ethical buying intention & $.08(.11)$ & $.47(1)$ & 1.08 & $5.23(8)$ \\
\hline Constant & $-1.25(.51)$ & $5.95(1)$ & $.29 *$ & \\
\hline \multicolumn{5}{|l|}{ Model 2: } \\
\hline Ethical buying intention & $.17(.21)$ & $.66(1)$ & 1.18 & $9.22(8)$ \\
\hline Awareness of animal testing policy (s) & $-.82(1.38)$ & $.35(1)$ & .44 & \\
\hline Ethical buying intention $\mathrm{x}$ awareness (s) & $-.15(.25)$ & $.36(1)$ & .86 & \\
\hline Constant & $-1.02(.57)$ & $3.24(1)$ & .36 & \\
\hline \multicolumn{5}{|l|}{ Model 3: } \\
\hline Ethical buying intention & $.66(.35)$ & $3.51(1)$ & 1.93 & $4.91(8)$ \\
\hline Awareness of general CSR activities (g) & $-2.78(2.02)$ & $1.89(1)$ & .62 & \\
\hline Ethical buying intention $\mathrm{x}$ awareness $(\mathrm{g}$ ) & $-.86(.38)$ & $5.15(1)$ & $.43^{*}$ & \\
\hline Constant & $-.46(.55)$ & $.68(1)$ & .63 & \\
\hline
\end{tabular}




\section{Discussion}

The current findings contribute to the existing literature on buying intention and buying behavior. They show that intentions are not correlated with behavior. Self-reported buying behavior is widely used in marketing research as it is a convenient method. Some companies assess consumers' buying intention as a means to forecasting the implementation of new products. This study shows that other factors could intervene between the buying intention and actual buying behavior (e.g. moral hypocrisy, lack of attribute information, lack of interest, or habitual buying). Thus, researchers should be aware of the limitations of this relationship when assessing their products' market performance.

This study also contributes to the CSR literature, as it found that ethical attitudes correlate with ethical buying intention and ethical buying intention does not correlate with ethical buying behavior when using a real situation, as suggested by Sen and Bhattacharya (2001). This relationship occurs when using the whole sample and when using only the sample where the CSR was known. Previous research investigated CSR's impact on consumers' buying intention and product evaluation using experimental methodology (Brown \& Dacin, 1997; Sen \& Bhattacharya, 2001; Ehrich \& Irwin, 2005). Although these studies could establish causal relationships between variables, they did not evaluate how consumers react to CSR in a real situation, where habitual buying might occur.

The current findings could be useful to managers who allocate resources on CSR initiatives, because it shows that in general consumers are not aware of this practice. Managers should find a better way to communicate their social actions and place emphasis on the consequences that might occur when they are not involved in these actions. However, it should be noted that the specific awareness of animal testing policy is not as helpful as the general awareness of the company's CSR activities. This is partly due to the consumers' wrong awareness of animal testing policy. However, even the company placed an emphasis on their general CSR activities, the link between their ethical purchase intention and actual purchase behavior is more easily established. Aside from this, for this particular case (i.e. shampoo products), the results could suggest that managers should concentrate their efforts on product attributes other than non-animal testing, because this alone does not lead to an increase in purchasing behavior. These findings could also be used by policy makers, who could encourage people to buy non-animal tested products. They should increase people's awareness about animal testing practice and its devastating effects on animals. This could be done by requiring cosmetics companies which test on animals to have information about these actions clearly labeled on their products.

\section{Conclusion and Future Research}

Although the relationship between attitudes and buying intention corresponds to the previous findings (Sheppard et al., 1988; Wilson et al., 1975), no significant relationship was found between buying intention and actual buying behavior with regards to their intention of buying animal tested shampoos. However, the significant relationship reappeared when controlling consumers' awareness of the company's CSR activities. These findings substantiate Ehrichm and Irwin's (2005) suggestion that consumers did not act on their ethical buying intention because of their unawareness of the company's CSR activities.

Three directions for future research are proposed. First is to extend this study into different consumer samples (e.g. housewives, businessmen, consumers with different socio-economical status) and ethical contexts (e.g. other CSR activities rather than animal testing). Moreover, comparisons could be made between consumers from different countries or between groups with extreme views about CSR issues (such as political activist, green organization member or the skeptical consumers who do not quite believe the use of CSR). Our knowledge of consumers' ethical consumption patterns could benefit from a more comprehensive research.

Second, future research could investigate consumers' emotions with respect to CSR actions. It might help explain the discrepancy between attitudes and buying behavior, the effect of cognitive dissonance (Festinger, 1957) in their ethical attitudes and behavior, and the reason why consumers' avoidance to deal with negative emotions. There are still many areas in real life situations waiting for us to explore and to understand why people purchase ethically; thereby helping policy makers as well as the businesses to turn CSR activities not just into legislation, but an economical value.

Third, future research is encouraged to examine how consumers search for product attribute information. Understanding how consumers search the information is important as it constitutes the basis for product evaluation. Voss, Spangenbers and Grohman (2003) argue that consumers consider both utilitarian (functional attributes) and hedonic (sensations associated with the product) product attributes when making purchasing choices as these influence their cognitive and affective involvement. Alternatively, product evaluation also depends on consumers' involvement in the purchasing decision (Olshavsky \& Granbois, 1979). More evidence is 
required to understand how consumers engage in extended attribute research prior to purchase with regard to CSR issues. These many areas await for our exploration.

\section{References}

Ajzen, I. (1991). The theory of planned behaviour. Organizational Behaviour and Human Decision Processes, 50(2), 179-211. http://dx.doi.org/10.1016/0749-5978(91)90020-T

Ajzen, I., \& Fishbein, M. (1977). Attitude-behaviour relations: a theoretical analysis and review of empirical research. Psychological Bulletin, 84(5), 888-918. http://dx.doi.org/10.1037/0033-2909.84.5.888

Anderson, L. R., \& Fishbein, M. (1965). Prediction of attitude from the number, strength, and evaluative aspect of beliefs about the attitude object. Journal of Personality and Social Psychology, 2(3), 437-443. http://dx.doi.org/10.1037/h0022220

Baker, M. J. (1991). Research for Marketing. Basingstoke: Macmillan Education.

Banwari, M. (1990). The relative roles of brand beliefs and attitude toward the ad as mediators of brand attitude: a second look. Journal of Marketing Research, 27(2), 209-219. http://dx.doi.org/10.2307/3172847

Baron, R. M., \& Kenny, D. A. (1986). The moderator-mediator variable distinction in social psychological research: conceptual, strategic, and statistical considerations. Journal of Personality and Social Psychology, 51(6), 1173-1182. http://dx.doi.org/10.1037/0022-3514.51.6.1173

Baston, C. D., Thompson, E. R., \& Chen, H. (2002). Moral hypocrisy addressing some alternatives. Journal of Personality and Social Psychology, 83(2), 230-339.

Bettman, J. R. (1982). A functional analysis of the role of overall evaluation of alternatives in choice process. Advances in Consumer Research, 9(1), 87-93.

Beutel, A. M., \& Marini, M. M. (1995). Gender and values. American Sociological. Review, 60(3), 436-448. http://dx.doi.org/10.2307/2096423

Bohlen, G., \& Schlegemilch, B. B. (1993). Measuring ecological concern: a multi-construct perspective. Journal of Marketing Management, 9(4), 415-430. http://dx.doi.org/10.1080/0267257X.1993.9964250

Bonfield, E. H. (1974). Attitude, social influence, personal norm, and intention interactions as related to brand purchase behavior. Journal of Marketing Research, 11(4), 379-389. http://dx.doi.org/10.2307/3151284

Boush, D. M., Friestad, M., \& Rose, G. (1994). Adolescent skepticism toward tv advertising and knowledge of advertiser tactics. Journal of Consumer Research, 21(1), 165-75. http://dx.doi.org/10.1086/209390

Brown, T. J., \& Dacin, P. A. (1997). The company and the product: corporate associations and consumer product responses. Journal of Marketing, 61(1), 68-84. http://dx.doi.org/10.2307/1252190

Bruvold, W. H. (1972). Consistency among attitudes, beliefs and behaviour. Journal of Social Psychology, 86(1), 127-134. http://dx.doi.org/10.1080/00224545.1972.9918603

Calder, B. J., Lynn, W. P., \& Tybout, A. M. (1981). Designing research for application. Journal of Consumer Research, 8(2), 197-207. http://dx.doi.org/10.1086/208856

Chandon, P., Morowitz, V. G., \& Reinartz, W. R. (2005). Do intentions really predict behavior? self-generated validity effects in survey research. Journal of Marketing, 69(2), 1-14. http://dx.doi.org/10.1509/jmkg.69.2.1.60755

Chattopadhyay, A., \& Alba, J. W. (1988). The situational importance of recall and inference in consumer decision making. Journal of Consumer Research, 15(1), 1-12. http://dx.doi.org/10.1086/209140

Cohen, J. (1988). Statistical power analysis for the behavioural science. Hillsdale, New York: Lawrence Erlbaum.

Drumwright, M. E. (1996). Company advertising with social dimension: the role of noneconomic criteria. Journal of Marketing, 60(4), 71-87. http://dx.doi.org/10.2307/1251902

Ehrich, K. R., \& Irwin, J. R. (2005). Wilful ignorance in the request for product attribute information. Journal of Marketing Research, 42(3), 266-277. http://dx.doi.org/10.1509/jmkr.2005.42.3.266

Engel, J. F., Blackwell, R. D., \& Kollat, D. T. (1990). Consumer behavior (6th ed.). USA: The Dryden Press.

Festinger, L. (1957). Theory of cognitive dissonance. Evanston: Row Peterson And Company.

Freedman, M., \& Jaggi, B. (1982). Pollution disclosures, pollution performance and economic performance. The 
International Journal of Management Science, 10(2), 167-176.

Gilbert, A., \& Churchill, J. R. (1979). A paradigm for developing better measures for marketing constructs. Journal of Marketing Research, 16(1), 64-73. http://dx.doi.org/10.2307/3150876

Grayson, K., Johnson, D., \& Chen, D. F. R. (2008). Is firm trust essential in a trusted environment? how trust in the business context influences customers. Journal of Marketing Research, 45(2), 241-256. http://dx.doi.org/10.1509/jmkr.45.2.241

Irwin, J. R., \& Naylor, R. W. (2009). Ethical decisions and response mode compatibility: weighting of ethical attributes in consideration sets formed by excluding versus including product alternatives. Journal of Marketing Research, 46(2), 234-246. http://dx.doi.org/10.1509/jmkr.46.2.234

Kalwani, M. U., \& Silk, A. J. (1982). On the reliability and predictive validity of purchase intention measures. Marketing Sceience, 1(3), 243-286. http://dx.doi.org/10.1287/mksc.1.3.243

Kapferer, J. N., \& Laurent, G. (1985). Measuring consumer involvement profiles. Journal of Marketing Research, 22(1), 41-53. http://dx.doi.org/10.2307/3151549

Kinnear, T., \& Taylor, J. R. (1973). The effect of ecological concern on brand perceptions. Journal of Marketing Research, 10(2), 191-7. http://dx.doi.org/10.2307/3149825

Kolodinsky, R. W., Madden, T. M., Zisk, D. S., \& Henkel, E. T. (2010). Aattitudes about corporate social responsibility: business student predictor. Journal of Business Ethics, 91(2), 167-181. http://dx.doi.org/10.1007/s10551-009-0075-3

Levitt, S. D., \& List, J. A. (2007). What do laboratory experiments measuring social preferences reveal about the real world? Journal of Economic Perspectives, 21(2), 153-174. http://dx.doi.org/10.1257/jep.21.2.153

Lifton, P. D. (1985). Individual differences in moral development: the relation of sex, gender, and personality to morality. Journal of Personality, 53(2), 306-334. http://dx.doi.org/10.1111/j.1467-6494.1985.tb00368.x

Luo, X., \& Bhattacharya, C. B. (2006). Corporate social responsibility, customer satisfaction, and market value. Journal of Marketing, 70(4), 1-18. http://dx.doi.org/10.1509/jmkg.70.4.1

Lynch, J. G. (1982). On the external validity of experiments in consumer research. Journal of Consumer Research, 9(3), 225-239. http://dx.doi.org/10.1086/208919

McQuarrie, E. F. (1998). Have laboratory experiments become detached from advertising goals? A meta-analysis. Journal of Advertising Research, 38(6), 15-26.

Morowitz, V. G., \& Schmittlein, D. (1992). Using segmentation to improve sales forecasts based on purchase intent. Journal of Marketing Research, 29(4), 391-405. http://dx.doi.org/10.2307/3172706

Olshavsky, R. W., \& Granbois, D. H. (1979). Consumer decision making—fact or fiction? Journal of Consumer Research, 6(3), 93-100. http://dx.doi.org/10.1086/208753

Punj, G. N., \& Staelin, R. (1983). A model of consumer information search behaviour for new automobiles. Journal of Consumer Research, 9(4), 366-380. http://dx.doi.org/10.1086/208931

Reynolds, F. D., \& Wells, W. D. (1977). Consumer Behaviour. New York: McGraw-Hill, Inc.

Schwartz, S. H. (1968). Words, deeds and the perception of consequences and responsibility in action situations. Journal of Personality and Social Psychology, 10(3), 232-242. http://dx.doi.org/10.1037/h0026569

Sen, S., \& Bhattacharya, C. B. (2001). Does doing good always lead to doing better? Consumer reactions to corporate social responsibility. Journal of Marketing Research, 38(2), 225-243. http://dx.doi.org/10.1509/jmkr.38.2.225.18838

Sheppard, B. H., Hartwick, J., \& Warshaw, P. R. (1988). The theory of reasoned action: a meta-analysis of past research with recommendations for modifications and future research. Journal of Consumer Research, 15(3), 325-43. http://dx.doi.org/10.1086/209170

Voss, K. E., Spangenberg, E. R., \& Grohmann, B. (2003). Measuring the hedonic and utilitarian dimensions of

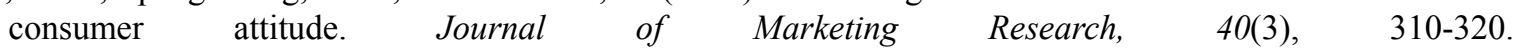
http://dx.doi.org/10.1509/jmkr.40.3.310.19238

Waddock, S. A., \& Graves, S. B. (1997). The corporate social performance - financial performance link. $\begin{array}{llll}\text { Strategic Management 303-319. } & \text { Journal, }\end{array}$ http://dx.doi.org/10.1002/(SICI)1097-0266(199704)18:4<303::AID-SMJ869>3.0.CO;2-G 
Whitmore, W. M. (1976). Mail survey premiums and response bias. Journal of Marketing Research, 13(1), 46-50. http://dx.doi.org/10.2307/3150900

Wilson, D. T., Mathews, H. L., \& Harvey, J. W. (1975). An empirical test of the fishbein behavioral intention mode. Journal of Consumer Research, 1(4), 39-48. http://dx.doi.org/10.1086/208606

Zelzny, L. C., Chua, P. P., \& Aldrich, C. (2000). Elaborating on gender differences in environmentalism. Journal of Social Issues, 56(3), 443-457. http://dx.doi.org/10.1111/0022-4537.00177

\section{Copyrights}

Copyright for this article is retained by the author(s), with first publication rights granted to the journal.

This is an open-access article distributed under the terms and conditions of the Creative Commons Attribution license (http://creativecommons.org/licenses/by/3.0/). 